DOI: $10.17951 / 1.2016 . X I V .2 .25$

A N N A LES

UNIVERSITATIS MARIAE CURIE-SKŁODOWSKA

LUBLIN - POLONIA

VOL. XIV, 2

SECTIO L

2016

Instytut Muzyki Uniwersytetu Marii Curie-Skłodowskiej

Renata GozDECKA

\title{
Dydaktyka uniwersytecka Beaty Dąbrowskiej. Przywotania chwil minionych
}

Beata Dąbrowska's University Teaching. Memories of the Past Moments

W chłodny wiosenny poranek 14 marca 2016 roku odeszła od nas Profesor Beata Dąbrowska - Dyrektor Instytutu Muzyki Wydziału Artystycznego UMCS, Kierownik Zakładu Dydaktyki Muzycznej i Muzykoterapii, dyrygent Chóru Kameralnego Towarzystwa Muzycznego im. Henryka Wieniawskiego w Lublinie, ceniony, niezapomniany pedagog. W ciągu ponadtrzydziestoletniej pracy pedagogicznej w Instytucie Muzyki UMCS wykształciła kilkudziesięciu absolwentów. Wielu z nich prowadzi dziś własne zespoły wokalne, chóry, zarówno w szkołach, jak i w innych placówkach związanych z działaniami edukacyjnymi, życiem muzycznym i sferą kultury. Prowadząc dydaktykę na naszym Uniwersytecie, Profesor Beata Dąbrowska niezmiennie służyła mądrą radą, dzieliła się doświadczeniem i umiejętnościami, a przy tym - dzięki szczerej pasji, wielkiemu zaangażowaniu i ujmującej osobowości - zarażała entuzjazmem do muzyki chóralnej.

W ramach dydaktyki uniwersyteckiej prowadziła kilka przedmiotów, zależnie od okresu - w różnych konfiguracjach. Były to: dyrygentura chóralna, czytanie partytur, zespót wokalny, metodyka prowadzenia zespolu wokalnego, Chór Mieszany Instytutu Wychowania Muzycznego (obecnie Chór Instytutu Muzyki) i literatura chóralna. Zajęcia z tych przedmiotów, mających oczywiście swoją 
merytoryczną i metodyczną autonomię, ogniskowały się wokół tego, co było Jej zawsze najbliższe - świata muzyki chóralnej.

Niech nasze przypomnienia niektórych epizodów z uniwersyteckiej pracy dydaktycznej Profesor Beaty Dąbrowskiej będą zatrzymaniem i upamiętnieniem choćby małej cząstki tego, co nam pozostawiła i czym zapisała się w naszych sercach $^{1}$.

\section{Dyrygentura chóralna}

Pierwsze zajęcia z dyrygentury chóralnej zawsze rozpoczynała od dłuższej rozmowy ze swoimi studentami, aby bliżej poznać osoby tworzące grupę - ich wiedzę muzyczną, zainteresowanie przedmiotem, stopień uczestnictwa w życiu muzycznym. Potem przedstawiała główne treści przewidziane w programie przedmiotu $^{2}$, przechodząc następnie do pierwszych problemów i ćwiczeń. Były

${ }^{1}$ Podstawę źródłową niniejszego tekstu stanowią dokumenty archiwalne z Instytutu Muzyki Wydziału Artystycznego UMCS, osobiste materiały Beaty Dąbrowskiej, udostępnione przez Jej męża, Dariusza Dąbrowskiego, oraz zapisy moich rozmów (maj 2016 rok) z Jej uczennicami: absolwentkami Instytutu Muzyki UMCS - Mileną Lis (obecnie nauczyciel akademicki w Instytucie Muzyki UMCS) i Izabelą Urban (obecnie dyrygent Zespołu Wokalnego „Sine Nomine”), oraz studentkami - Kingą Rdzak i Jagodą Pondel. Prezentowane w artykule fotografie pochodzą ze zbiorów Dariusza Dąbrowskiego.

${ }^{2}$ Treści programowe przedmiotu (dostępne w USOS) podporządkowane były modułowym efektom kształcenia opracowanym dla dyrygentury chóralnej przez pedagogów Instytutu Muzyki UMCS prowadzących ten przedmiot, a zespołowi temu przewodniczyła Dyrektor Beata Dąbrowska. Program dyrygentury chóralnej opisany został następująco: „Student posiada znajomość techniki dyrygenckiej w zakresie potrzebnym do realizowania repertuaru zespołów szkolnych i amatorskich zespołów placówek pozaszkolnych; posiada wiedzę w zakresie form, gatunków i cech stylistycznych w odniesieniu do utworów muzyki chóralnej, wokalno-instrumentalnej i instrumentalnej, określonych programem przedmiotu; ma wiedzę na temat analizowania partytur utworów różnych epok i stylów oraz przełożenia ich na język gestów, w zakresie repertuaru określonego programem przedmiotu; posiada znajomość podstawowego repertuaru realizowanego w ramach przedmiotu; swobodnie posługuje się schematami dyrygenckimi, ma wykształconą niezależność rąk, posiada praktyczną umiejętność stosowania odpowiednich gestów dyrygenckich w celu przekazania manualnej informacji odnośnie do agogiki, dynamiki, artykulacji i frazowania w utworze muzycznym; umie analizować partytury pod względem formalnym, w zakresie repertuaru określonego programem przedmiotu; potrafi zaprojektować, przygotować i wykonać z zespołem określony repertuar; wykorzystuje wiedzę teoretyczną, umiejętności, wyobraźnię i wrażliwość muzyczną w kształtowaniu interpretacji utworu; potrafi pełnić funkcję dyrygenta w zespole, biorąc odpowiedzialność za jego organizację i działalność artystyczną; ma świadomość poziomu swojej wiedzy ogólnomuzycznej oraz umiejętności w zakresie techniki dyrygowania i rozumie potrzebę ich doskonalenia; potrafi sformułować sądy i oceny dotyczące własnych prezentacji oraz występów innych zespołów”. 
to kolejno: postawa dyrygenta, ruch przygotowawczy, uwrażliwienie na różnice między taktowaniem a dyrygowaniem, a także wstępne, najbardziej elementarne gesty manualne. Jednocześnie wprowadzała podstawowe schematy metryczne, ćwiczenia na opanowanie różnorodnych przebiegów rytmicznych, zwracała też uwagę na zróżnicowanie funkcji rąk.

Jej praca podczas cotygodniowych spotkań była bardzo uporządkowana, a repertuar realizowany w trakcie zajęć każdorazowo odpowiadał wybranym na dany dzień problemom merytorycznym i celom metodycznym. Wśród zagadnień pierwszego semestru (poza wymienionymi wcześniej) znajdowały się, m.in.: zatrzymanie i rozpoczęcie ruchów rąk przypadających na każdą miarę taktu, kierowanie ruchów w stronę poszczególnych grup głosowych, prawidłowe ustawienie chóru. Wszystkie poznane schematy metryczne utrwalane były na materiale prostych pieśni wielogłosowych, co dotyczyło również i kwestii artykulacyjnych, omawianych i ćwiczonych na podstawie specjalnie w tym celu wyselekcjonowanych utworów. Bazą repertuarową wypełniającą program pierwszego semestru były wybrane pieśni kompozytorów polskich ze zbioru Józefa Karola Lasockiego Z pieśnia, przeznaczonego na czterogłosowy chór mieszany, obok nich także piosenki ludowe na dwu- i trzygłosowy chór dziecięcy w opracowaniu Marii Dziewulskiej, w czasie bożonarodzeniowym zaś - kolędy Andrzeja Nikodemowicza. Często podczas analizowania partytur Profesor Dąbrowska zalecała wysłuchanie nagrania utworu w dobrym wykonaniu.

Owe pierwsze spotkania z Beatą Dąbrowską na dyrygenturze chóralnej tak wspominają Jej byłe studentki:

„Pani Profesor nie uczyła nas z żadnych książek, choć wspominała o takowych, nie wymagała definicji. Uczyła skrupulatnie postawy, schematów, pracowała $\mathrm{z}$ nami przed lustrem, zwracała szczególną uwagę na punkt powrotu ręki - to ważne w nauce schematów dyrygenckich - żeby nie był rozmyty, tylko bardzo czytelny. Mówiła, że nie jest zainteresowana wychowywaniem swoich kopii. Dawała miejsce na indywidualność - co dziś uznaję za bardzo cenne; sugerowała, że wiele spraw ruchowych, technicznych powinno wiązać się z predyspozycjami uczącego się. Dostrzegała w nas różnice i dostosowywała swoją pracę do fizycznych predyspozycji każdego z nas. Uruchamiała każdego studenta i wskazywała mu właściwą postawę, biorąc pod uwagę jego wzrost i budowę ciała. Tworzyliśmy, wspólnie z kolegą, dość kontrastowy osobowo skład na zajęciach, jednak nie stanowiło to dla Niej bariery. Akcentowała, że mężczyzna jako dyrygent ma nieco inne możliwości niż kobieta, zatem ważna jest właściwa postawa, by eksponowała i wykorzystywała jak najlepiej atuty przyszłego dyrygenta" (Izabela Urban). 
„Pani Profesor miała wypracowaną kolejność działań metodycznych: pracę nad wybraną kompozycją rozpoczynała od ustalenia prawidłowej postawy dyrygenta, właściwych schematów metrycznych oraz występujących w utworze podstawowych struktur rytmicznych. Za każdym razem kazała nam tak dyrygować, jakbyśmy trzymały w rękach pędzel i malowały po ścianie. Jeśli utwór miał tekst słowny, to omawiałyśmy jego treść, tłumaczyłyśmy niezrozumiałe słowa, charakteryzowałyśmy kompozytora i epokę, z której pochodziło dzieło. Po opanowaniu schematu następowała praca nad elementami technicznymi - odbitki, nuty z kropką, dynamika, budowanie napięcia we frazach, żeby pokazać emocje w tym utworze. Poza tym należy dodać, że Pani Profesor miała bardzo wysoki próg oceniania, co nas motywowało do pracy; przez całe studia licencjackie żadna $\mathrm{z}$ nas nie miała oceny bardzo dobrej, zdarzyło się to jedynie na egzaminie końcowym" (Kinga Rdzak, Jagoda Pondel).

„Pamiętamy śmieszne momenty, kiedy mówiła, że musi mnie przywiązać do podłogi, bo się za bardzo kołysałam” (Jagoda Pondel). „Mnie kazała dyrygować z kijem od miotły, bo łokcie mi za bardzo wychodziły na boki. Włożony kij za plecy bardzo mi pomógł i z biegiem czasu widzę tego pozytywny rezultat" (Kinga Rdzak).

„Podczas zajęć często wykorzystywałyśmy lustro. Pani Profesor stała z boku lub obok nas, zdarzało się, że podchodziła z tyłu i jeśli nie potrafiłyśmy dobrze wykonać wymaganego elementu, to brała nasze ręce i nimi pokazywała właściwe ruchy. Po takim praktycznym ćwiczeniu wiedziałyśmy, jak wykonać omawianą frazę. Zawsze przekazywała nam utwór tydzień wcześniej, abyśmy się przygotowały, i odpytywała nas z tego. Pamiętamy też wiele różnych powszechnie nieznanych ciekawostek, które nam opowiadała, i dzięki którym zapamiętałyśmy poznane utwory. Szczególnie ceniła osobę profesora Andrzeja Nikodemowicza, o którego życiu - szczególnie podczas poznawania jego kolęd - sporo nam opowiadała" (Kinga Rdzak, Jagoda Pondel).

„Swoją współpracę z Panią Profesor mogę omówić z kilku perspektyw - ucznia, akompaniatora, chórzysty i zastępcy dyrygenta. Pamiętam, że pierwsze spotkania opierały się na analizach podstawowych schematów, które były szczegółowo rozpisywane, dalsza zaś praca dotyczyła doskonalenia koordynacji obu rąk w utworach jednogłosowych. Zwracała uwagę - zgodnie z wybieranym w tym celu repertuarem - na określone wartości rytmiczne, metrum, kolejno wprowadzała utwory dwugłosowe, na głosy żeńskie. Były to na początku nietrudne utwory ludowe, następnie poznawałyśmy Mazurka Dąbrowskiego, Gaude Mater Polonia, Gaudeamus 
igitur - wszystko już w czterogłosie. Nie było wypracowanego modelu chronologicznego omawiania dzieł, jednak polifonia pojawiła się znacznie później. Po utworach wokalnych Pani Profesor stopniowo wprowadzała utwory wokalno-instrumentalne" (Milena Lis).

W drugim semestrze Beata Dąbrowska kładła nacisk na utrwalanie ćwiczonych wcześniej schematów metrycznych oraz doskonalenie umiejętności odczytywania kolejnych ważnych elementów zawartych w partyturze, wraz z opanowaniem stosownych do tego umiejętności praktycznych. Dotyczyły one - między innymi - realizacji fermaty, różnicowania artykulacyjnego (np. staccato, legato), akcentów albo określonych grup rytmicznych (np. synkopa, rytmy punktowane); omawiane były również podstawowe zasady prowadzenia frazy i problemy kształtowania warstwy dynamicznej. Semestr drugi kończył się pracą nad utworami o fakturze polifonicznej. Podstawę muzyczną wszystkich tych zagadnień stanowiły wybrane pozycje ze wspomnianego już zbioru Józefa Karola Lasockiego, kompozycje na chór mieszany Stanisława Moniuszki, psalmy Mikołaja Gomółki oraz wielkopostne pieśni Andrzeja Nikodemowicza.

W trzecim semestrze utrwalane były nabyte uprzednio umiejętności, jednocześnie dochodziły nowe zagadnienia i wymagania. W tej fazie nauczania Beata Dąbrowska zwracała większą uwagę na oddanie za pomocą gestu różnicowania przebiegu metro-rytmicznego, uwrażliwiała na kontrasty artykulacyjne i dynamiczne, podczas pracy nad utworem eksponowała wagę tekstu słownego jako elementu istotnie współtworzącego frazę i strukturę muzyczną, najczęściej na przykładach dzieł z okresu renesansu, uczyła wreszcie techniki wprowadzania głosów w partiach imitacyjnych. Studenci dyrygowali - między innymi - utworami ze zbioru Lasockiego, psalmami Gomółki, kolędami Nikodemowicza, pieśniami Moniuszki, nadto wybranymi częściami z Missa brevis d-moll Antonia Lottiego.

Podczas ostatniego semestru, poza szlifowaniem opanowanych wcześniej sprawności, mierzono się z ambitniejszym i bardziej wymagającym repertuarem: dziełami polifonicznymi, utworami a cappella o większym stopniu trudności, a także kompozycjami wokalno-instrumentalnymi oraz instrumentalnymi, do czego równocześnie dochodziła praca nad rozwijaniem indywidualnych predyspozycji dyrygenckich poszczególnych studentów. W tym też czasie Profesor Dąbrowska ustalała repertuar na egzamin końcowy z przedmiotu. Jej zalecenia i rady tak wspomina Izabela Urban:

„Pamiętam uwagi dotyczące płaszczyzn dyrygowania zespołem, umiejscowienie wizualne, aby gesty były wyżej kierowane do zespołu wokalnego, niżej zaś do orkiestry. Wówczas czuło się, że uczy nas praktyk. Analizując przygotowywany w tym celu utwór wokalno-instrumentalny, krok 
po kroku wskazywała i często zaznaczała w nutach ważne dla dyrygenta miejsca. Mówiła, że dyrygent oddycha z frazą, i kiedy chór to widzi, łatwiej odczytuje jego plan, strategię. Mówiła, że nie da się wszystkiego «wydyrygować», trzeba wybrać istotne elementy (najpierw je zobaczyć, mieć tę umiejętność), np. wprowadzić głos lub jakieś trudne rytmicznie wejście głosu, żeby chór był pewien, że to tutaj - wskazywała nam te rzeczy, ale zaczynała od pytania, co my widzimy? Wymagała, abyśmy znali ważne określenia wykonawcze. To była bardzo solidna praca".

Warto dodać, że w każdym semestrze dyrygentury chóralnej pracowano przynajmniej nad pięcioma utworami, spośród których trzy należało opanować na pamięć. Ustne zaliczenie poznanego materiału obejmowało rozmowę na temat przygotowanych do prezentacji dzieł, m.in.: ich budowy formalnej, oznaczeń agogicznych, dynamicznych, artykulacyjnych, wejść poszczególnych głosów, z uwzględnieniem także charakterystyki sylwetek kompozytorów i epoki, w której powstał dany utwór. Przy dziełach wokalnych i wokalno-instrumentalnych ważne były również wiedza o autorze umuzycznionych słów oraz znajomość przekładów tekstów obcojęzycznych (np. łacińskich śpiewów kościelnych, włoskich madrygałów). Beata Dąbrowska wielokrotnie podkreślała, że dyrygent musi rozumieć treść śpiewanych tekstów; miała tu na uwadze również teksty ludowe oraz staropolskie, z ich archaizmami i zwrotami współcześnie już nieużywanymi.

Przy wszelkich metodycznych założeniach i merytorycznych wyborach przyjmowanych z myślą o dydaktycznej stronie dyrygentury chóralnej Profesor Dąbrowska szczególnie wysoko sytuowała praktyczny wymiar kształcenia, spełniający się $\mathrm{w}$ bezpośredniej pracy $\mathrm{z}$ chórem. Jak napisała $\mathrm{w}$ swoim programie nauczania, do realizacji przedmiotu niezbędne są żywe uczestnictwo w chórze i uważna obserwacja dyrygentów podczas prób i koncertów. Owo „podpatrywanie" mistrzów batuty uznawała za istotny element nauki, o czym wielokrotnie mówiła swoim studentom i do czego ich namawiała.

Ważnym aspektem pedagogiki chóralnej Beaty Dąbrowskiej był wybór repertuaru muzycznego. Określonym problemom warsztatowym i omawianym zagadnieniom przydzielała starannie dobrane kompozycje, dążąc równocześnie do tego, aby każdorazowo - w miarę możliwości - były one dostosowane do zdolności i umiejętności studentów, a także do ich indywidualnych preferencji. Obowiązkiem studenta było wcześniejsze zebranie podstawowych wiadomości na temat zadanego utworu.

Warto w tym miejscu zaprezentować rejestr kompozycji, które tworzyły repertuarowy kanon dyrygentury chóralnej, po części już nieco odsłonięty. Najpierw wymieńmy pozycje dobierane dla początkowej fazy zajęć. Były to śpiewy historyczne, m.in.: Bogurodzica, Gaude Mater Polonia, Gaudeamus igitur 
i Mazurek Dąbrowskiego, oraz proste opracowania polskich melodii ludowych, m.in.: dwugłosowe Tańcujże, karczmareczko i Kiej się zejdziemy, Powiedział mi z Łowickiego, A dajże mi Boże na trzygłosowy chór mieszany.

Zestaw dzieł wielogłosowych - zarówno twórców obcych, jak i rodzimych - obejmował pozycje od epoki renesansu do czasów współczesnych, głównie dzieła a cappella. Z repertuaru XVI-wiecznego pojawiały się m.in.: Amatemi ben mio Luki Marenzia, anonimowe Oczy me mite i motet $O$ magnum mysterium Tomása Luisa de Victoria. Utwory te służyły jako materiał do nauki poprawnego pokazywania wejść głosów w kompozycjach czterogłosowych, wypracowania czytelnych i precyzyjnych gestów dla zmian agogicznych, dynamicznych oraz rozwiązań opóźnień harmonicznych.

Jeśli chodzi o epokę baroku, Profesor Dąbrowska często sięgała po Stabat Mater Giovanniego Battisty Pergolesiego. To słynne dzieło, napisane na sopran, alt, smyczki i organy, wielokrotnie wykonywała - w całości bądź we fragmentach - zarówno z Chórem Towarzystwa Muzycznego, jak i ze studentami w ramach zespołu wokalnego. Wybieraną na potrzeby zajęć z dyrygowania część Quando corpus wykorzystywała do nauczania pokazywania wejść solistkom, panowania nad czteromiarowym schematem i przebiegiem dynamiki. Spośród kompozycji Johanna Sebastiana Bacha natomiast często brała na warsztat Sicut locutus est z monumentalnego Magnificatu. Z tytułem tym wiąże się sympatyczny epizod przypomniany przez Izabelę Urban:

„Umiejętności czytelnego eksponowania wejść poszczególnych głosów w fakturze polifonicznej ćwiczyliśmy na bazie fragmentu wielkiego dzieła Bacha [tj. Magnificat], zapewne dlatego, że utwór ten znany był wszystkim studentom z zajęć chóru. Pamiętam, że podczas mojego egzaminu końcowego członkowie komisji wspomagali akompaniatora, śpiewając kolejno pojawiające się głosy chóralne - każdy «zalogował» się do wybranego głosu i zabrzmiało spontanicznie wykonane dzieło. Ta sytuacja zdaje się obrazować familiarność, jaka panowała w naszym Instytucie i którą po latach bardzo dobrze wspominam".

Dzieła barokowe reprezentowała też Missa brevis d-moll Antonia Lottiego, z której zazwyczaj wybierane były dwie części: Kyrie i Agnus Dei. Kompozycja Lottiego, wyróżniająca się mistrzostwem na tle innych utworów kościelnych swoich czasów, „osiągnęla głębię wyrazu rzadko spotykaną w religijnej muzyce włoskiej"’; i na ten właśnie element - ekspresyjny - Beata Dąbrowska zwracała

${ }^{3}$ A. Żórawska-Witkowska, Lotti Antonio, [w:] Encyklopedia Muzyczna PWM. Część biograficzna, red. E. Dziębowska, t. 5, Kraków 1997, s. 421. 
szczególną uwagę podczas pracy nad Missa brevis, nie zaniedbując naturalnie innych ważnych elementów techniczno-interpretacyjnych: pokazywania wejść poszczególnych głosów, dokonywania zmian dynamicznych (piano, crescendo), kończenia fraz.

Spośród dzieł okresu klasycyzmu Beata Dąbrowska preferowała utwory Wolfganga Amadeusza Mozarta. Pierwszy z nich, motet Ave verum corpus, zawsze traktowany był jako pozycja obowiązkowa. Napisany na cztery głosy mieszane, instrumenty smyczkowe i organy, służył młodym adeptom dyrygentury do opanowania umiejętności dokładnego pokazania momentu wejścia chóru po instrumentalnym wstępie, rozwijania fraz melodycznych zgodnie z oznaczeniami dynamicznymi, uwydatnienia walorów ekspresyjnych dzieła. Drugim utworem było ogniwo Sanctus z Requiem d-moll. Wybór ten podyktowany był przypuszczalnie wieloma czynnikami; spośród nich na pewno duże znaczenie miała okoliczność, iż Requiem to jedno z największych, najbardziej znanych i najczęściej wykonywanych dzieł sakralnych Mozarta. Jak wspominają uczniowie Profesor Dąbrowskiej, praca nad Sanctus wiązała się przede wszystkim z nauką dyrygowania kompozycją wokalno-instrumentalną, równocześnie z rozwijaniem umiejętności czytelnego wprowadzania głosów i panowania nad zmianami metro-rytmicznymi. Inną, dodatkowo wykorzystywaną Mozartowską kompozycją był Menuet z Eine kleine Nachtmusik.

Z twórczości powstałej w pierwszej połowie XX stulecia Profesor Dąbrowska wykorzystywała regularnie dzieła kilku kompozytorów, wśród nich Kołysankę Jana Maklakiewicza, napisaną do wiersza Konstantego Ildefonsa Gałczyńskiego. Wzruszająca, liryczna, refleksyjna, ćwiczona była w trzech wersjach: na chór męski, na chór mieszany i na głos z fortepianem. Utwór dawał sposobność do utrzymywania dyscypliny w prowadzeniu spokojnego tempa i dopilnowania, aby frazy śpiewano na jednym oddechu. Spośród kompozycji Karola Szymanowskiego w programie dyrygentury chóralnej znalazła się pieśń A chtóz tam puka (z Sześciu pieśni kurpiowskich) - utwór wybrany ze względu na zróżnicowanie artykulacyjne (legato i staccato), złączone z wolnym tempem i zmianami dynamiki. Dyrygowanie taktów trójmiarowych w szybkim tempie, $\mathrm{z}$ zastosowaniem fermat $\mathrm{i}$ akcentów rytmicznych, wiązało się z pracą nad Mazurem Piotra Maszyńskiego, utrwalanie zaś wskazań dla artykulacji legato i staccato wspomagała pieśń Tadeusza Szeligowskiego Pod okapem śniegu. W programie przedmiotu znalazły się ponadto kompozycje Artura Malawskiego pochodzące z Małej suity chóralnej, opracowanej na czterogłosowy chór mieszany a cappella (W Wojtusiowej izbie i Malowane miski), oraz Wesele Sieradzkie Karola Prosnaka - jeden z ulubionych utworów Profesor Dąbrowskiej.

Spośród kompozycji współczesnych, powstałych na przestrzeni ostatnich dziesięcioleci, do programu dyrygowania wprowadzane były: Czego chcesz od 
nas, Panie i Jubilate Deo Józefa Świdra, A Little Jazz Mass brytyjskiego kompozytora Boba Chilcotta, utrzymany w stylistyce chorału gregoriańskiego utwór Ubi caritas autorstwa Ola Gjeilo oraz kolędy i pieśni wielkopostne Andrzeja Nikodemowicza, które u Beaty Dąbrowskiej zawsze miały swoje specjalne miejsce.

Wymienione utwory, figurujące $\mathrm{w}$ autorskich programach dydaktycznych Profesor Dąbrowskiej, stanowiły stały element zajęć z dyrygentury chóralnej. Należały zarazem - co potwierdzają rozmowy ze studentami - do najbardziej przez Nią lubianych.

Owe regularnie wykorzystywane pozycje repertuarowe nie wyczerpują pełnego spektrum materiału przerabianego na zajęciach dyrygentury chóralnej. Archiwalne rękopisy i programy tego przedmiotu z lat dziewięćdziesiątych i późniejszych pokazują, że mniej lub bardziej okazjonalnie Beata Dąbrowska pracowała ze studentami nad wieloma innymi kompozycjami, należącymi do różnych epok, gatunków i form. Były to dzieła i opracowania następujących twórców: Mikołaja z Krakowa (Aleć nade mna Wenus) ${ }^{4}$, Mikołaja Gomółki (psalmy 11, 45, 81, 103), Stanisława Moniuszki (Postój piękna gołąbeczko, Przylecieli sokołowie, Kum i kuma, Groźna dziewczynka, Nawrócona, Grajek, Znasz li ten kraj), Wilhelma Troszela (Młodo zeswatana), Antona Brucknera (Locus iste), Władysława Żeleńskiego (Zaczarowana królewna), Zygmunta Noskowskiego (W lesie z cyklu Cztery pory roku), Miłosza Kotarbińskiego (Cichy wieczór), Feliksa Nowowiejskiego ( $Z$ tej tam strony wody), Karola Szymanowskiego (Hej, wótki moje, Wyrzundzaj sie, dziwce moje, Spraw, niech płacze z Toba razem ze Stabat Mater), Kazimierza Sikorskiego (Powiedziat mi, Czemuście mnie, mamuliczko), Tadeusza Szeligowskiego (W moim ogródeczku z cyklu 5 pieśni ludowych z Lubelszczyzny), Feliksa Rybickiego (Łaczko, łaczko), Karola Prosnaka (Dwie myszki (żarcik)), Edmunda Maćkowiaka (Uwoz Mamo roz), Józefa Karola Lasockiego (Oj, świeci miesią), Witolda Rudzińskiego (Oj, zakwitto ziótko), Jana Krenza (Dwie śpiewki (smutna $i$ wesoła)), Józefa Świdra (Cuda i dziwy) i Romualda Twardowskiego ( $A$ w niedzielę raniusieńko z Suity warmińskiej).

Choć Profesor Beata Dąbrowska była artystą i dydaktykiem spełniającym się przede wszystkim w działaniach praktycznych, to niekiedy także ujawniała swoje teoretyczno-metodyczne przemyślenia. W 2014 roku - po wygłoszonej prelekcji podczas warsztatów z zakresu prowadzenia zespołów wokalnych - opublikowała artykuł, w którym podzieliła się wieloletnimi doświadczeniami ze swojej pracy

${ }^{4}$ Zaznaczmy, że przez lata Aleć nade mna Wenus uznawano za kompozycję (madrygał) Mikołaja z Krakowa. Jak się okazało w 1996 roku, jest to intawolacja włoskiej vilotty De là da l'acqua sta la mia amorosa, prawdopodobnie autorstwa Francesca Patavina. Zob.: P. Poźniak, Koniec legendy o polskim madrygale, „Muzyka” 41: 1996, nr 3, s. 59-71. 
w dziedzinie chóralistyki ${ }^{5}$. Na marginesie dodajmy, że wspomniane warsztaty realizowane były w ramach projektu unijnego „Profesjonalizm w edukacji. Przygotowanie i realizacja nowego programu praktyk pedagogicznych na Wydziale Artystycznym UMCS", a Beata Dąbrowska - jako Dyrektor Instytutu Muzyki - pełniła w przygotowaniu i urzeczywistnieniu tego projektu kluczowe funkcje. W przywołanym tekście starała się przybliżyć młodym adeptom chóralistyki ważne aspekty profesji dyrygenckiej, które prawdopodobnie odkryje przed nimi przyszła praca zawodowa. Pisała tak:

„Relacje występujące podczas artystycznego przedsięwzięcia, jakim jest wykonanie dzieła wokalno-instrumentalnego, można porównać do zależności powstających podczas każdej pracy zespołowej. Wielu badaczy uważa, że praca w zespole jest istotą prawie każdej działalności zawodowej, a dobre relacje osobiste wpływają na sprawne funkcjonowanie zespołu $^{6}$. Twierdzenia te $\mathrm{z}$ pewnością można przenieść na interesujący nas grunt. Wiele prawidłowości występujących $\mathrm{w}$ grupie podczas pracy zawodowej znajdziemy także w sytuacji amatorskiego muzykowania. Dostrzeżemy podział ról oraz różne rodzaje porozumiewania się, tworzące relacje oficjalne i nieformalne. Porozumiewanie się oficjalne można podzielić na oddolne, obejmujące kontakty podwładnego z szefem; porozumiewanie odgórne obejmuje wiadomości od przełożonych do podwładnych, np. uzasadniające wykonanie lub sposób wykonania czynności; porozumiewanie poziome - między osobami niepozostającymi w zależności służbowej, lecz dotyczące spraw służbowych. Pozostaje także porozumiewanie się nieformalne, opierające się na przyjacielskich stosunkach i wspólnych interesach zawodowych i osobistych ${ }^{7}$. Analizując te stwierdzenia, łatwo można zauważyć analogie: kontakty chórzysty z dyrygentem, wiadomości przekazywane przez dyrygenta za pośrednictwem chórmistrza, rozważania dotyczące problemów wykonawczych toczące się między chórzystami, wreszcie prywatne, nieformalne kontakty między zaprzyjaźnionymi członkami chóru. W wykonaniu dzieła wokalno-instrumentalnego (oraz przygotowaniu wykonania) najczęściej biorą udział soliści, chór lub chóry, chórmistrz, orkiestra i dyrygent. W związku z tym relacji zachodzących podczas prób i koncertu nie można ograniczyć wyłącznie do kwestii kontaktów chóru i dyrygenta. Można przyjąć, że poszczególne relacje tworzą się na nastę-

${ }^{5}$ B. Dąbrowska, Specyficzne relacje i zależności między wspótwykonawcami dzieła wokalno-instrumentalnego, [w:] Wieloaspektowe działania muzyczne we współczesnej przestrzeni kulturowej, red. R. Gozdecka, Lublin 2014, s. 55-62.

${ }^{6}$ Zob.: R. B. Adler, L. B. Rosenfeld, R. F. Proctor II, Relacje interpersonalne. Proces porozumiewania się, przeł. G. Skoczylas, Poznań 2011, s. 7.

${ }^{7}$ Ibid., s. 418-419. 
pujących poziomach: chórzysta - dyrygent; chór - członkowie orkiestry; chór - soliści; orkiestra - soliści; orkiestra, soliści - dyrygent; chór - chór; dyrygent przygotowujący chór - dyrygent całości wykonywanego dzieła"».

Ową szczególną relację: chórzysta - dyrygent, w odniesieniu do nauki pod kierunkiem Beaty Dąbrowskiej, tak wspominają Milena Lis i Izabela Urban:

„Będąc studentką Pani Profesor, obserwowałam funkcjonowanie Chóru Towarzystwa Muzycznego można powiedzieć z bliska, od pierwszego roku stałam się członkiem chóru, a na II roku studiów pojechałam z grupą do Belgii. Wówczas pogłębiła się nasza relacja, gdyż poza rolą studentki podczas zajęć dyrygowania w Instytucie stałam się chórzystą, doświadczającym bezpośrednio wielu ważnych działań, widziałam swojego nauczyciela w roli, do której przygotowuje mnie podczas zajęć. Często - pamiętając, że uczestniczyłam w pracy z chórem nad jakąś kompozycją - potrafiła odwołać się do wielu występującym w niej problemów. Na piątym roku - z uwagi na realizowaną specjalność - dużo pracowała ze mną indywidualnie, omawiałyśmy kilka utworów wokalno-instrumentalnych, takich jak Lacrimosa z Requiem Mozarta czy Msza jazzowa Boba Chilcota, którymi dyrygowałam podczas egzaminu końcowego. Profesor wielokrotnie zachęcała mnie do dyrygowania wybranymi utworami podczas koncertów Chóru Towarzystwa Muzycznego, mawiała: «pójdź, nauczysz się pracy z chórem, oswoisz się z tremą». W ostatnim czasie przejmowałam rolę dyrygenta częściej, to było niezwykłe doświadczenie, bardzo wartościowe dla studenta" - wspomina Milena Lis.

„Te dwie rzeczy - nauka dyrygowania na studiach i uczestnictwo w chórze Towarzystwa Muzycznego jakoś się uzupełniały" - mówi Izabela Urban. „Miałam to szczęście, że byłam jednocześnie uczniem i chórzystą, widziałam Ją podczas koncertów, Jej pracę z utworem, komunikację, nigdy nie działałyśmy w oderwaniu od praktyki, dobrze było to obserwować. Byłam rocznikiem, który mógł sobie wybrać nauczyciela. Wcześniej miałam kontakt ze Zdzisławem Oharem, byłam zarażona tematem chóru. «A dlaczego ty do tej Pani?» - pytano mnie. «A bo Ona ma fajny chór i repertuar». To był świadomy wybór nauczyciela, tytuł naukowy nie miał znaczenia.

Podczas pracy nad wybranym fragmentem utworu pokazywała frazy własnym gestem, jednak dawała studentowi dużo wolności, sugerowała, aby zadyrygować po swojemu, pokierować tak, żeby odczuć coś osobistego. Powtarzała, że nawet najlepszy warsztat dyrygencki - taki «w rękach» - nie zastąpi kontaktu z chórem; jak chór już zna dyrygenta, to zrobi

\footnotetext{
${ }^{8}$ Dąbrowska, op. cit., s. 57.
} 
wszystko. Kiedy po ukończeniu studiów podjęłam pracę z zespołem „Sine Nomine", zaprosiłam Ją na swój pierwszy koncert. Wówczas, poza radosnym uśmiechem i gratulacjami, dostałam również uwagi, które wzięłam do serca: «nie opuszczaj pretensjonalnie rąk, przytrzymaj, jeszcze trwa dźwięk, a ty już opuszczasz». O tej uwadze pamiętam do dziś".

We wspomnianym artykule Beata Dąbrowska, rozpatrując wielorakie relacje interpersonalne zachodzące podczas żywej prezentacji dzieła wokalno-instrumentalnego, dostrzegała również rangę odbiorcy, do którego przecież artysta-dyrygent kieruje swoją interpretację:

„Duża różnorodność relacji interpersonalnych, występująca podczas wykonania dzieła wokalno-instrumentalnego, może stanowić źródło badań i analiz dla psychologów społecznych. Zespoły chóralne czy orkiestrowe, zarówno amatorskie, jak i profesjonalne, na pewno są grupami interesującymi badawczo. Jednak pomimo tak bogatego aparatu wykonawczego, jaki stanowią soliści, chóry, orkiestra, dyrygent, nie można zapomnieć o innym aspekcie wykonania - reakcji odbiorcy muzyki. Relacja wykonawcy - publiczność pozostaje jedną z najważniejszych, nadaje sens muzycznym działaniom"”.

\section{Czytanie partytur}

Przedmiot czytanie partytur obecny jest w programie studiów Instytutu Muzyki UMCS od początku istnienia kierunku. Realizowany był - w zależności od obowiązujących w danym czasie standardów programowych - na różnych latach i semestrach, przy zmieniającym się też wymiarze godzinowym. Przedmiot ma na celu zapoznanie studentów z różnego rodzaju partyturami, poczynając od wielogłosu wokalnego, przez rozmaite inne obsady wykonawcze, kończąc na partyturach instrumentalnych (od kwartetu smyczkowego po aparat orkiestrowy), oraz - co naturalnie najistotniejsze - wykształcenie umiejętności gry na fortepianie analizowanych partytur. Dopełnieniem treści przedmiotu jest czytanie w starych kluczach i zaznajomienie się z podstawowymi zasadami sporządzania wyciągu fortepianowego. Nabycie wskazanych kompetencji ma skądinąd służyć również zgłębieniu i opanowaniu przez studentów tych kompozycji, nad którymi pracują w ramach dyrygentury chóralnej oraz na zajęciach „chóru instytutowego” i zespołu wokalnego.

\footnotetext{
${ }^{9}$ Ibid., s. 61.
} 
Beata Dąbrowska prowadziła ten przedmiot - a wiemy to z Jej osobistych notatek - w latach dziewięćdziesiątych, w ramach dwóch semestrów na III roku studiów. Pracę rozpoczynała od utworów wokalnych o fakturze homofonicznej, przeznaczonych na rozmaite dyspozycje głosowe. Materiał nutowy stanowiły opracowane przez Marię Dziewulską piosenki ludowe na głosy równe i zespół instrumentalny w łatwym układzie, a także wybrane pozycje zbioru $Z$ pieśniq Lasockiego (zeszyty 1-3). W pierwszym semestrze rozczytywano wybrane z tej publikacji trzy- i czterogłosowe pieśni przeznaczone na chór mieszany oraz pieśni Stanisława Moniuszki ze zbioru Pieśni wybrane na trzygłosowy chór mieszany (sopran, alt, głos męski) z fortepianem. W zestawie tym znalazła się ponadto kompozycja Andrzeja Koszewskiego Modre oczka, napisana na chór żeński.

Jak powiedziano, przedmiot obejmował również praktykę czytania w starych kluczach. Jeśli chodzi o dobór materiału demonstracyjnego i konkretnych problemów, Beata Dąbrowska przyjmowała następującą kolejność: klucz altowy - łączenie z kluczem basowym; klucz tenorowy - łączenie z basowym oraz łączenie z kluczem altowym (po dwa głosy); czytanie trzech linii melodycznych - w kluczach altowym, tenorowym i basowym; klucz sopranowy - łączenie z poznanymi wcześniej kluczami po dwa głosy jednocześnie, następnie po trzy głosy jednocześnie; czytanie w czterogłosie - zestaw w czterech kluczach, ćwiczony na czterogłosowych chorałach Bacha.

W drugim semestrze przedmiotu rozwijane były umiejętności czytania w starych kluczach. Tym razem za materiał służyły wydane przez Stanisława Wiechowicza trzygłosowe utwory dawnych mistrzów z XIII-XVIII wieku. Dochodziły do tego inne jeszcze pozycje, m.in.: utwory homofoniczne na większą liczbę głosów (od pięciu do ośmiu głosów) ze wspomnianego zbioru Lasockiego (zeszyty 3-4), dzieła o fakturze polifonicznej (motety i madrygały renesansowe), kompozycje o rozszerzonej harmonice, m.in. Pieśni kurpiowskie Karola Szymanowskiego, oraz współczesne utwory chóralne.

W dawnych planach studiów z lat dziewięćdziesiątych zdarzało się czasem, że niektóre roczniki miały czytanie partytur przez cztery semestry. Wówczas zakres wymaganych treści poszerzony był o partytury przeznaczone na zespoły smyczkowe (trio, kwartet, kwintet) i małą orkiestrę, analizowano nadto wybrane symfonie na pełny skład orkiestrowy, a także utwory skomponowane na nietypowe składy, przeznaczone głównie na instrumenty transponujące. W notatkach Beaty Dąbrowskiej napotykamy dwie propozycje związane z ową rozszerzoną wersją przedmiotu: Ignacego Feliksa Dobrzyńskiego Duet na klarnet i róg oraz Josepha Forestiera 12 duetów na trąbki (w różnych strojach).

Warto w tym miejscu przypomnieć, że w prowadzonych przez Beatę Dąbrowską zajęciach z czytania partytur pojawiały się również ćwiczenia wokalne, 
w różnych przy tym odmianach; na przykład: student miał za zadanie grać jeden lub dwa głosy i jednocześnie śpiewać inny głos albo jedna osoba realizowała partyturę, druga śpiewała wybrany jej głos.

Materiał nutowy wykorzystywany przez Beatę Dąbrowską na czytaniu partytur stanowiły często pieśni przewidziane w programie dyrygentury chóralnej oraz dla zajęć z chóru i zespołu wokalnego, wspomniane wcześniej wydawnictwa Józefa Karola Lasockiego i Stanisława Wiechowicza ${ }^{10}$ oraz podręczniki do nauki czytania partytur autorstwa Edwarda Burego i Hanny Piliczowej ${ }^{11}$.

\section{Literatura chóralna}

Literaturę chóralna wprowadziła Profesor Dąbrowska w ostatnich latach jako nowy przedmiot w programie studiów Instytutu Muzyki, przydzielając go specjalności prowadzenie zespołów (w ramach fakultetu specjalizacyjnego). Z relacji studentów uczestniczących w tych zajęciach wiemy, że materiał omawiała w porządku chronologicznym, począwszy od renesansu, kończąc na czasach współczesnych. W sporządzonych przez Nią sylabusach przedmiotu znajdowały się kolejno następujące tematy: formy muzyki religijnej w okresie renesansu; madrygał $\mathrm{i}$ inne formy muzyki świeckiej okresu renesansu ${ }^{12}$; muzyka polska w okresie renesansu i baroku; Johann Sebastian Bach i Georg Friedrich Haendel: formy wokalno-instrumentalne w twórczości mistrzów baroku; twórczość oratoryjna i mszalna klasyków wiedeńskich; romantycy w twórczości na chór a cappella; twórczość chóralna przełomu XIX i XX wieku, i pierwszej połowy XX wieku; współczesna twórczość chóralna kompozytorów polskich. Prezentując i analizując wybrane przykłady muzyczne, Profesor Dąbrowska stosowała metody wy-

${ }^{10}$ J. K. Lasocki, Z pieśnia, Warszawa 1979; S. Wiechowicz, Ćwiczenia w starych kluczach, cz. II: J. S. Bach, Choraty, Kraków 1978.

${ }^{11}$ E. Bury, Technika czytania partytur, Kraków 1971; H. Piliczowa, Nauka czytania partytur. Materiały pomocnicze do wykładów i ćwiczeń, Warszawa 2004.

${ }^{12}$ Wśród prywatnych notatek Profesor Dąbrowskiej znajduje się dokument zatytułowany: Literatura chóralna, w którym zestawione zostały - jak można przypuszczać - wykorzystywane podczas zajęć renesansowe kompozycje; były to następujące utwory: Gregorio Allegri, Miserere; John Bennet, Weep, O mine Eyes; William Byrd, Kyrie i Ave verum corpus; Pierre Certon, Je ne l'ose dire; John Dowland, Come Again; Carlo Gesualdo, Luci serene; Andreas Hakenberger, Exsultate; Clément Jannequin, Bitwa pod Marignan; Orlando di Lasso, Chi, Chilichi, Matona mia cara i Echo; Luca Marenzio, Cosi moriro; Thomas Morley, Now is the Month of Maying; Giovanni Pierluigi da Palestrina, Stabat Mater; Pierre Passereau, Il est bel et bon; Thomas Tallis, Lamentacje Jeremiasza; Thomas Tomkins, See, See the Shepheards' Queene; Thomas Weelkes, Since Robin Hood. 
kładu informacyjnego, opisu i dyskusji dydaktycznej, zaliczenie przedmiotu zaś polegało na wykazaniu się wiedzą na temat przerobionego materiału.

Dla bodaj fragmentarycznego „odtworzenia” zajęć z literatury chóralnej przywołajmy słowa Izabeli Urban, nieuczestniczącej w nich wprawdzie, ale bardzo blisko w ostatnim czasie współpracującej z Beatą Dąbrowską:

„Bardzo lubiła te zajęcia i bardzo się z nich cieszyła, zawsze chciała się do tych zajęć przygotować jak najlepiej. Pracowała korzystając z list utworów pogrupowanych na tablecie, jednak na początku nosiła na zajęcia płyty, które wybierała ze swojego prywatnego, ogromnego zbioru. Przygotowywała konkretne utwory, które były pomocne w zrozumieniu określonego - wybranego przez Nią - zagadnienia. Mówiła, że są epoki, w których czuje się mniej zorientowana, jak na przykład średniowiecze; prosiła, abym wybrała jakieś «hity», żeby studentom pokazać, że nie tylko się biczowali i jeździli na koniach, ale że tworzono też radosne dzieła.

Była ciekawa współczesnych interpretacji muzyki dawnej, nie należała do zacietrzewionych purystów, doceniała eksperymenty Jana Garbarka, Leszka Możdżera czy Christiny Pluhar. Mawiała, że warto pokazywać takie przykłady, jednak pod warunkiem, że się powie, iż nie jest to wykonawstwo historyczne, i nie pominie się oryginalnych wersji.

Każda audycja muzyczna miała swój temat. Mówiła, że nie sposób studentów zapoznać choćby z namiastką ważnych i wartościowych dzieł, wiedziała, że ma na to za mało czasu, ale czuła odpowiedzialność, że pewne tytuły student powinien znać. W tym widziała swoje zadanie, misję. Kładła nacisk na bardzo dobre wykonania tych utworów, mawiała - «przedstawiajmy sztukę najwyższej próby!» Nawet jeśli studenci tego nie docenią, warto pracować tak, żeby nie mieć do siebie pretensji, że się pokazało coś byle jakiego (bo tego nie lubiła).

Muzyka renesansu stanowiła ważny obszar Jej zainteresowań. Wiem, że europejskiej muzyki świeckiej słuchała z konkretnych płyt i rekomendowała je studentom ${ }^{13}$. Barok ją fascynował, ale lubiła też romantyzm.

${ }^{13}$ Były to m.in.: Banchieri, Commedie Harmoniche - Comedies Madrigalesques (Concerto Italiano); Bonjour, mon coeur (Collegium Vocale Bydgoszcz); Carlo Gesualdo, Madrigaux a 5 voix (William Christie, Les Arts Florissants); Chants d'amour, chants de guerre (Ensemble Candor Vocalis); Chansons (Collegium Vocale Bydgoszcz); Dowland - First Booke of Songes (Anthony Rooley: Consort Of Musicke); "Draw on Sweet Night" - English Madrigals (różni wykonawcy); From Morley to McCartney (Affabre Concinui); King's Singers Madrigals (The King's Singers); Le chant des Oiseaux (Ensemble Clément Jannequin); Luca Marenzio, Madrigali - Il piu dolce cigno (Concerto Italiano); Madrigal History Tour (The King's Singers); Monteverdi, Il Terzo Libro di Madrigal (La Venexiana); Monteverdi, Quarto libro dei madrigali (Consort Of Musicke); Villanelle, 
Odzwierciedlił to program przewodu kwalifikacyjnego drugiego stopnia, którego trzon stanowily psalmy Feliksa Mendelsohna.

Należała do ludzi, którzy nie robią swoich zajęć sztampowo, nie pracowała według konspektu punkt po punkcie. O muzyce często mówiła $\mathrm{z}$ wielkimi emocjami, porównywała wykonania koncertowe z interpretacjami płytowymi, wskazywała na różnice, akcentowała walory, eksponowała mocne i słabe strony wykonań".

Pedagogiczną pracę Profesor Beaty Dąbrowskiej nieustannie zasilały Jej piękne cechy osobowościowe, wywierające wpływ na wszystkich, którym dane było się u Niej kształcić. Pamiętają dziś o tym Jej ostatnie uczennice:

„Mówiła, że my jesteśmy dla niej jak córki; tak nas troszkę traktowała, chociaż był między nami dystans właściwy dla relacji: uczeń - profesor. Jednak Ona bardzo się interesowała nami (co się dzieje, jak coś nam nie wychodzi?), żeby wiedzieć, jak do nas dotrzeć, czy nie mamy jakichś problemów, czy coś złego nie dzieje się w naszych duszach... Była osobą bardzo serdeczną, ciepłą, opanowaną. Pani Profesor nigdy nie stresowała nas, nie krzyczała, nie używała podniesionego głosu, ale wzbudzała respekt i wielki szacunek; bałyśmy się przyjść nieprzygotowane - to by nas krępowało" (Kinga Rdzak, Jagoda Pondel).

Wspomnienia te - jakże zgodne z moimi własnymi odczuciami sprzed lat (miałam bowiem przyjemność być Jej uczennicą) - zaświadczają, że pracowała z wyjątkowym spokojem, opanowaniem; stawiając wymagania, wytwarzała ciepłą, pełną serdeczności atmosferę. Miało to źródło w wielu innych Jej przymiotach, niezwiązanych tylko ze sferą dydaktyki. Zawsze z cierpliwością, zaciekawieniem i wyrozumiałością słuchała różnych racji. Nie złościła się, kiedy ktoś nie wypełnił obowiązku. Emanowała z niej skromność, raczej ustępowała miejsca. Wszelkie zaszczyty przyjmowała ze zdziwieniem, zdawała się później o nich nie pamiętać. Nigdy nie strofowała studentów za brak wiedzy czy nieprzygotowanie; $w$ takich momentach odsyłała do biblioteki, kierowała do innych źródeł, mobilizowała - nie zawstydzała. Cechowała Ją wielka kultura osobista, z każdego Jej działania przebijał szacunek dla człowieka. 
Pobrane z czasopisma Annales L - Artes http://artes.annales.umcs.pl

Data: 26/04/2023 13:27:17

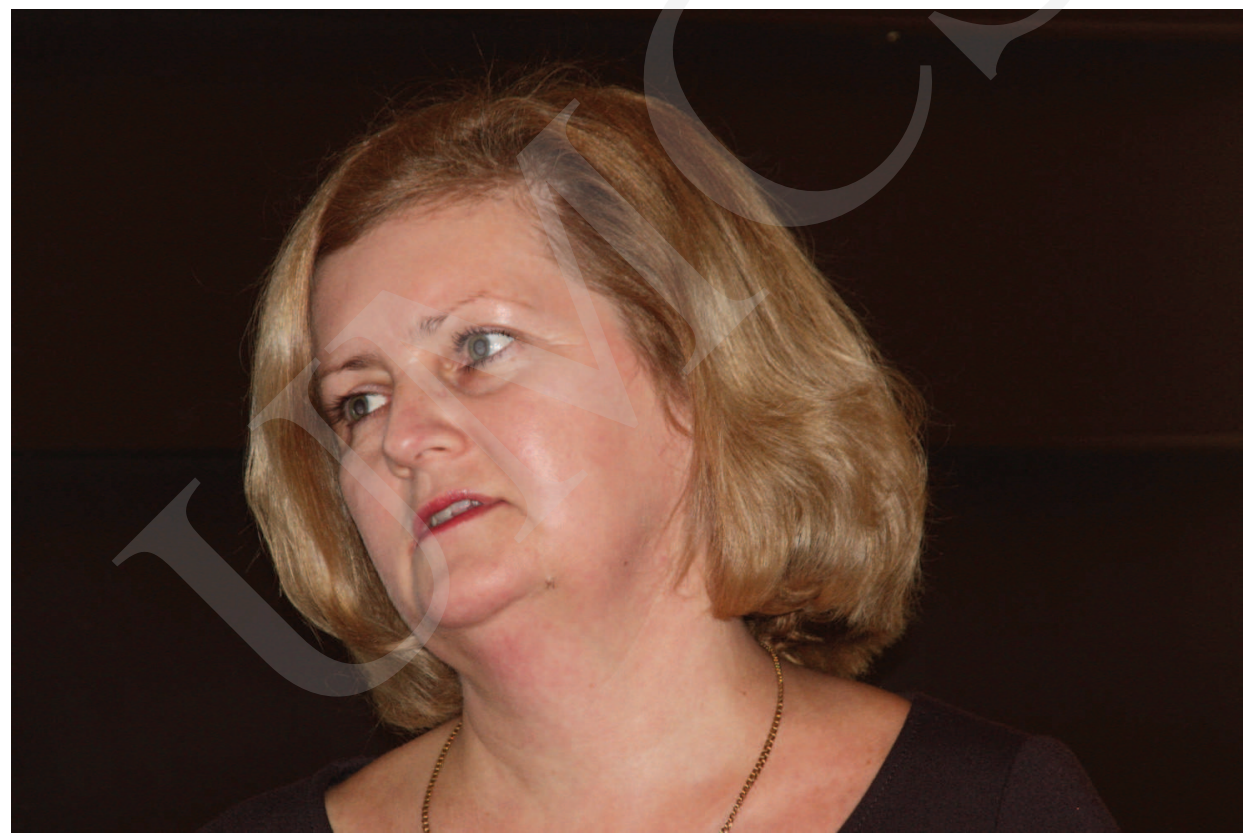

Fot. 1. Beata Dąbrowska (2008). 
Pobrane z czasopisma Annales L - Artes http://artes.annales.umcs.pl

Data: 26/04/2023 13:27:17

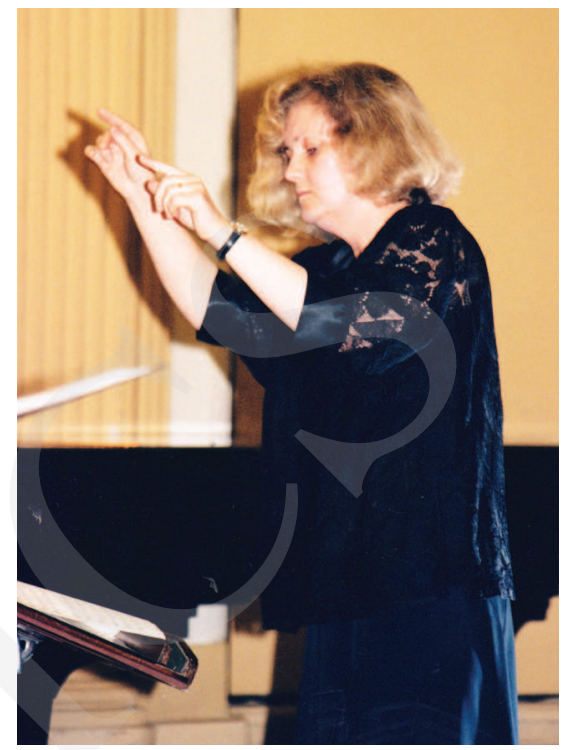

Fot. 2. Podczas próby (1992).

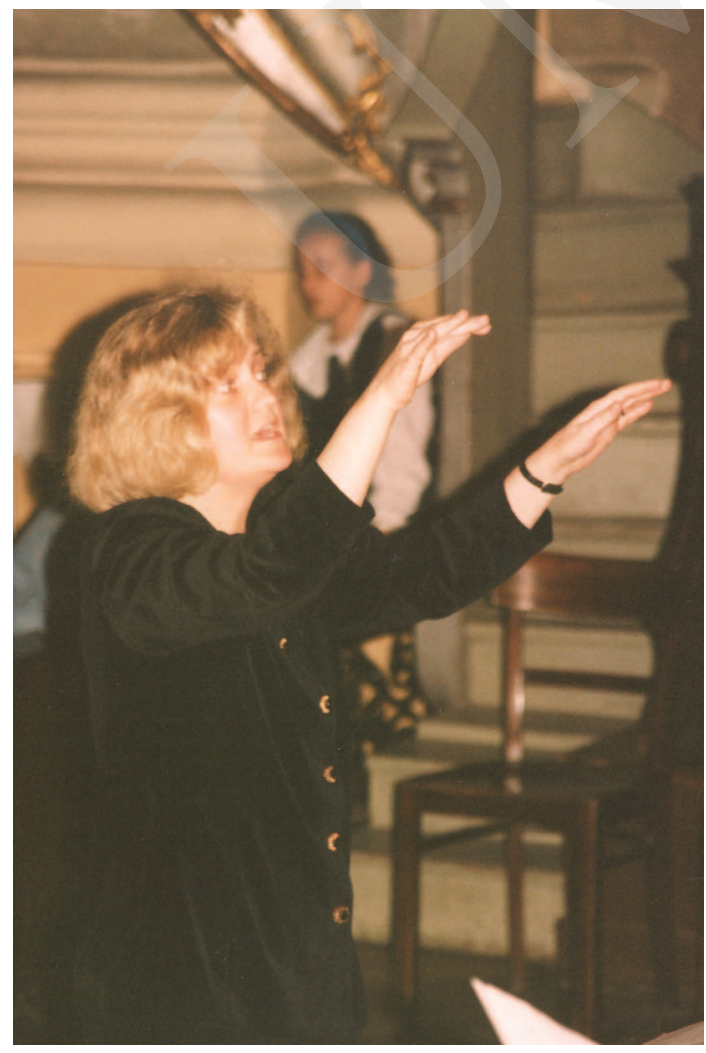

Fot. 3. Podczas koncertu (1992). 


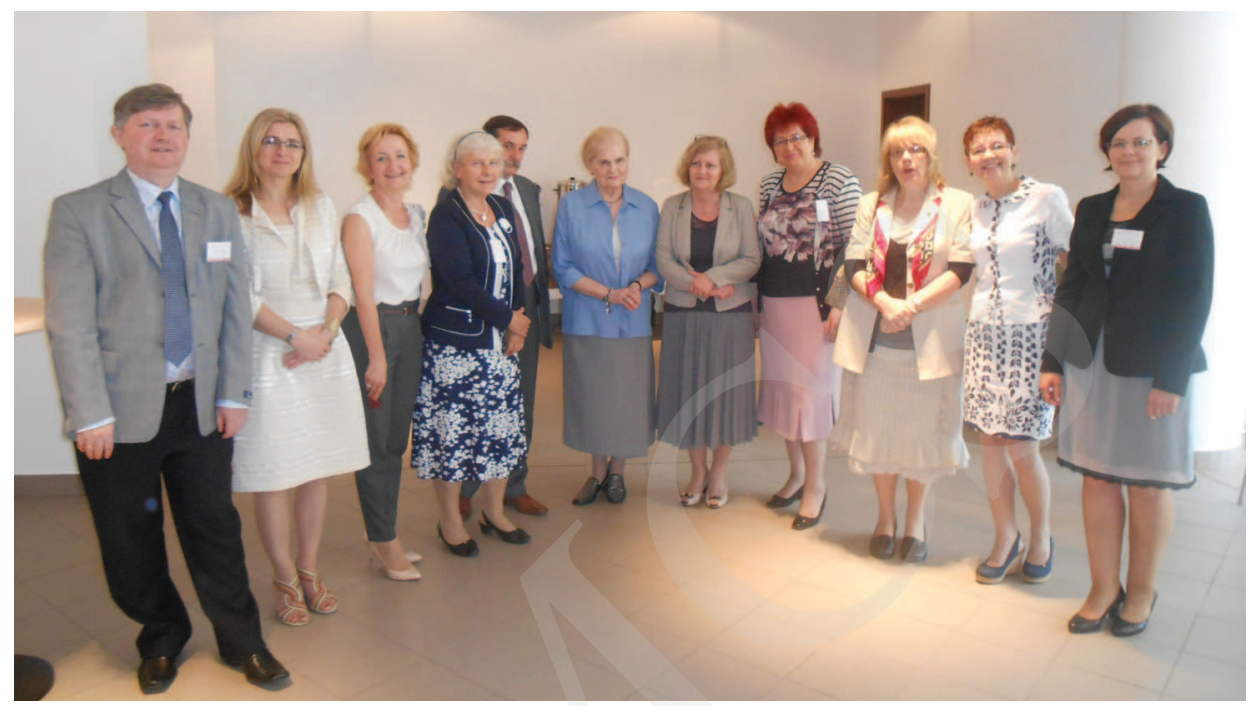

Fot. 4. W kuluarach Ogólnopolskiej Konferencji Naukowej zorganizowanej z okazji jubileuszu 40 lat kształcenia artystycznego na UMCS (czerwiec 2013), od lewej: Mariusz Dubaj, Renata Gozdecka, Elżbieta Krzemińska,

Zofia Konaszkiewicz, Andrzej Białkowski, Maria Przychodzińska, Beata Dąbrowska, Beata Kamińska-Kłos, Barbara Jedlewska, Anna Janosz, Agata Kusto.

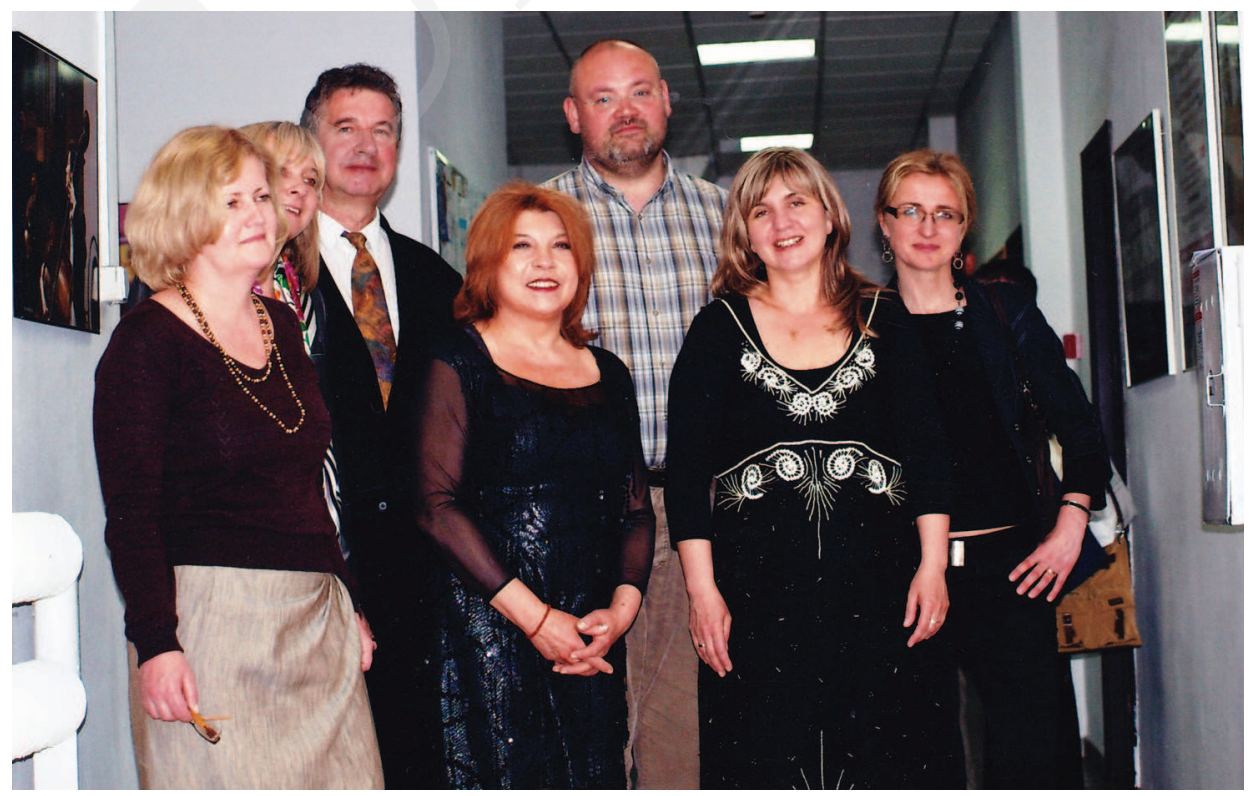

Fot. 5. W Filharmonii Lubelskiej po Nadzwyczajnym Koncercie V Charytatywnego Maratonu Koncertowego „Młodzi Muzycy - Muzykom Seniorom” (2009), od lewej: Beata Dąbrowska, Urszula Bobryk, Marek Stefankiewicz, Krystyna Prońko, Adam Czajkowski, Monika Mielko-Remiszewska, Renata Gozdecka. 
Pobrane z czasopisma Annales L - Artes http://artes.annales.umcs.pl

Data: 26/04/2023 13:27:17

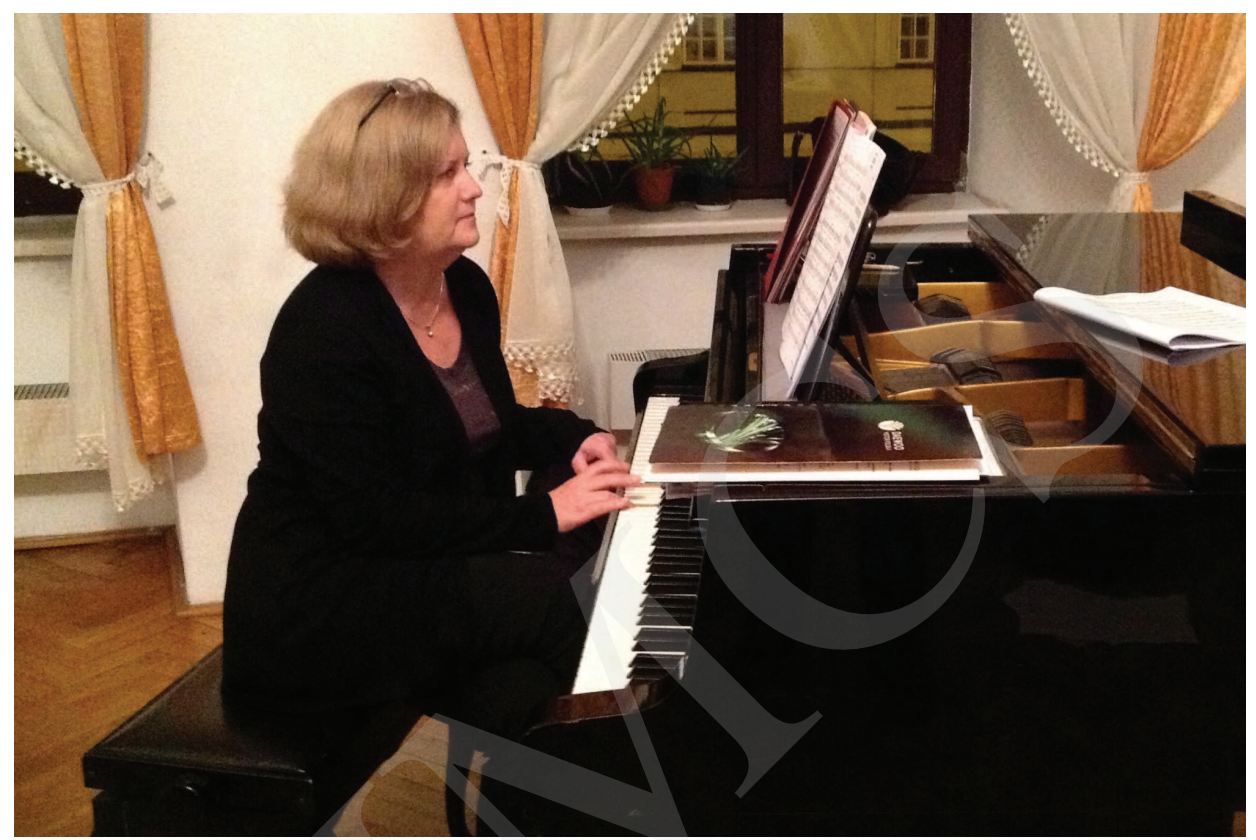

Fot. 6. W sali Towarzystwa Muzycznego im. Henryka Wieniawskiego w Lublinie (2012).

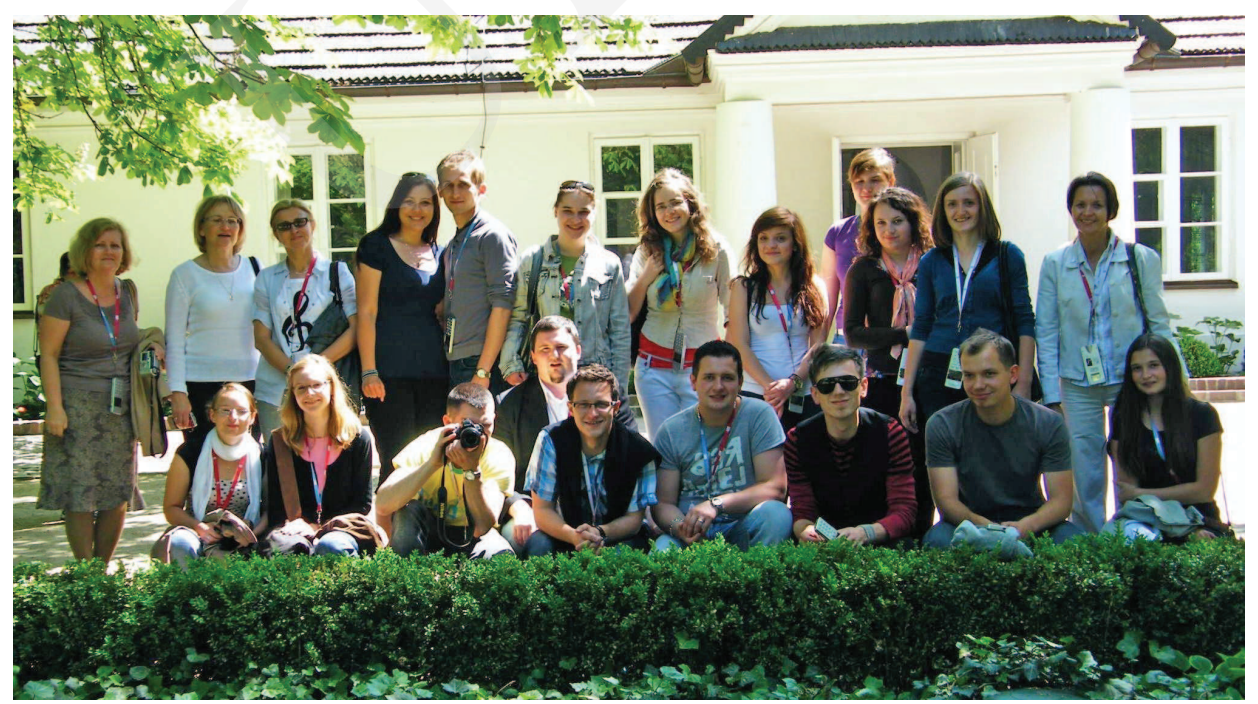

Fot. 7. W Żelazowej Woli z grupą studentów Instytutu Muzyki UMCS (maj 2011), w górnym rzędzie od lewej: Beata Dąbrowska, Jadwiga Jasińska, Renata Gozdecka, Agata Bondos, Łukasz Cholewa, Melania Laskowska, Edyta Oleksiuk, Magdalena Litwin, Eliza Jackowska-Boryc, Diana Krzemińska, Agnieszka Góra, Anna Wójcik; w dolnym rzędzie od lewej: Katarzyna Mandziuk, Milena Lis, Piotr Wierzchowski, Wojciech Fus, Jakub Urbański, Damian Kulik, Michał Mirosław, Adam Bąbik, Aleksandra Wójcik. 
„Na chwilę tu jestem i tylko na chwilę" - pisała Wisława Szymborska ${ }^{14}$. Takiej właśnie chwili mieliśmy szczęście zaznać z Beatą Dąbrowską. Pamięć o tym wieloletnim spotkaniu pozostanie $\mathrm{w}$ nas trwała, o tę pamięć będziemy zawsze dbali, a w ważnych momentach - do niej wracali; nieodmiennie mając nadzieję, że - by przywołać słowa ks. Jana Twardowskiego - „można odejść na zawsze, by stale być blisko" ${ }^{15}$.

\section{SUMMARY}

The article presents the teaching work of Beata Dąbrowska (1960-2016) at Maria Curie-Skłodowska University, Institute of Music. During over 30 years of her work at the University, Beata Dąbrowska - a conductor and teacher - educated several dozen graduates. As part of her teaching duties, she taught courses in choral conducting, reading the scores, vocal band, methodology of conducting vocal band, and in choir and choral literature. The classes in these subjects focused on choral music, which she liked the most. This text presents the methods and the style of her work during classes in choral conducting, reading the scores and choral literature. The description of her teaching, including, inter alia, manual and technical aspects of conducting, repertoire and interpretative issues, has been complemented with the remembrances by her students: graduates of the Institute of Music: Milena Lis and Izabela Urban and students - Kinga Rdzak and Jagoda Pondel. These memories confirm that Professor Dąbrowska - a person of great personal culture conducted her classes with extreme calm and self-control. She was a demanding teacher but at the same time she created a warm and cordial atmosphere.

\footnotetext{
${ }^{14}$ W. Szymborska, Wiersze wybrane, Warszawa 2010, s. 182.

${ }^{15}$ Z wiersza Bez tytulu. Na Powązach warszawskich. Cyt. [za:] J. Twardowski, Można odejść na zawsze, by stale być blisko, Warszawa 2015, s. 125.
} 